\title{
A practical, low-cost, short-term storage method for genomic DNA
}

Demir Özdemir*, 1 (iD

${ }^{1}$ Department of Agricultural Biotechnology, Faculty of Agriculture, Akdeniz University, 07070, Antalya, Turkey; *Author for correspondence: dozdemir@akdeniz.edu.tr

BioTechniques 70: 00-00 (April 2021) 10.2144/btn-2020-0158

First draft submitted: 17 November 2020; Accepted for publication: 25 February 2021; Published online: 22 March 2021

\section{ABSTRACT}

The aim of this study was to assess the DNA preservation capability of cellulose paper towel and blotting paper as low-cost alternatives to commercial DNA preservation products. Chicken blood was applied as DNA source to each paper towel, blotting paper, FTA ${ }^{\circledR}$ cards and DNA/RNA Shield ${ }^{T M}$. All samples were stored at room temperature for 130 days. DNA extraction from dried blood spots was performed after various time periods using Tris-EDTA and $\mathrm{NaOH}$ protocols. PCR activity and the mean amount of DNA isolated from paper towels were reliable. The results of this study demonstrated that cellulose-based blotting paper and especially paper towel had considerable DNA binding and preservation capacity for at least 130 days at room temperature without DNA degradation.

\section{METHOD SUMMARY}

Chicken blood was applied to each paper towel, blotting paper, FTA ${ }^{\circledR}$ cards and DNA/RNA Shield ${ }^{T M}$. DNA extraction from dried blood spots was performed after various time periods using Tris-EDTA and $\mathrm{NaOH}$ protocols. The quality of the extracted DNA was determined by PCR amplification of chicken CHD1 gene fragment. The results of this study demonstrated that cellulose-based blotting paper and especially paper towel had considerable DNA binding and preservation capacity for at least 130 days at RT without degradation.

\section{KEYWORDS:}

cellulose $\bullet$ DNA preservation $\bullet$ dried blood spots $\bullet$ FTA $\bullet$ paper towel

The collection of animal blood samples for genomic DNA extraction is one of the essential parts of molecular studies on animals. The laboratory delivery and storage of blood samples obtained from animals without the degradation of DNA is a major obstacle for researchers during field studies, where samples often need to be preserved at the point of collection. DNA extraction cannot always be performed during sample collection, and samples must be stored intact for a period of time until analysis. Researchers are therefore interested in different preservation and storage methods of DNA in a wide range of fields and disciplines, such as biomedical research, diagnostics and forensics. Freezing is the most widely used preservation method for samples collected for DNA analyses for longterm storage [1]. However, it is also challenging to freeze samples instantly in field experiments and there is always a threat of thawing over long distances during shipment or long-term field studies [2]. Thus drying the blood samples is considered a cost-efficient method preferred in field studies, as its ease during transport allows it to protect DNA from degradation for a long time at room temperature.

The ability of cellulose to bind DNA has made it the main material used in dry preservation methods. In the case of adding blood or other hydrophilic solvents to the paper, produced by compressing pure cellulose fibers to varying degrees, cellulose causes the paper to swell due to the degradation of the hydrogen bonds between the polymers. Organic molecules in the blood can also interact with the hydrogen bonds of cellulose or fill in the voids and macromolecules, such as proteins and DNA, by entering the gaps between the fibrous layers. Therefore drying the paper allows it to revert to its corresponding state because molecules become trapped in the cellulose matrix. Molecules dried in the cellulosic paper are more stable because they are preserved from the environmental conditions and stabilized by the cellulose spine [3]. In a similar way, cellulose has also proven its ability to preserve DNA in studies in plants [4]. This feature makes cellulose an valuable material for DNA preservation.

Although the collection of blood samples on cellulose paper was first recognized by Ivar Christian Bang over a century ago [5,6], the widespread use of dried blood spots (DBSs) to test for phenylketonuria in newborns was only reported in the early 1960s [7]. The DBS process entails the of collection of blood spots directly onto a cellulose-based paper and then leaving them to dry at room temperature before shipping to laboratories for analysis [8]. In addition to their widespread use in human health, DBSs are also becoming increasingly common in animal research, such as veterinary diagnostics [9], animal molecular genetics [10,11], clinical pharmacokinetic studies [12,13] and toxicokinetics $[14,15]$.

With recent developments in cellulosic paper modification and processing innovations, various commercial products based on cellulose are used for capturing and storing blood samples, such as FTA ${ }^{\circledR}$ (Fast Technology Analysis) cards that are chemically modified to lyse cells, denature proteins, prevent bacterial growth and protect nucleic acids from nucleases and oxidative and UV damage, accord- 
ing to the manufacturer's instructions [16-18]. Although these commercial products are sensitive and have advantages for molecular assays, they still have a limitation for low-budget research due to the high costs per sample. Given the DNA binding ability of cellulose, this study aimed to test the DNA preservation capability of cellulose-based paper towel and blotting paper as low-cost alternatives to DNA preservation products.

\section{Materials \& methods}

\section{Source of DNA}

In the experiment, fresh chicken blood, as a source of DNA, was applied to the $100 \%$ pure cellulose paper towel, cellulose blotting paper $\left(60 \mathrm{~g} / \mathrm{m}^{2}\right)$, FTA $^{\circledR}$ classic cards (Whatman, MA, USA) and DNA/RNA Shield ${ }^{\mathrm{TM}}$ (Zymo Research, CA, USA) to test the storage time and preservation ability of DNA. The blood samples used in this study were provided from the experimental material of project BAP-20194824 and all experimental protocols were approved by Akdeniz University Council for Ethical Licensing of Animal Experiments, ethical permit no 828/2019.01.01.

\section{Sample preparation}

The paper towel and blotting papers used in the experiment were cut into $4-\mathrm{cm}^{2}$ pieces and were then autoclaved to prepare the samples. Equal amounts of blood (50 $\mu$ leach) were added on the paper towel, blotting paper and FTA ${ }^{\circledR}$ classic cards. All the samples were then left to dry for $6 \mathrm{~h}$ at room temperature to form DBSs, then the dried samples were stored in separate clean tubes at room temperature for 130 days until DNA isolation. The DNA/RNA Shield was prepared according to the manufacturer's instructions. Chicken blood (50 $\mu$ ) was mixed with $100 \mu \mathrm{l}$ DNA/RNA Shield for the sample preservation. The DNA/RNA Shield samples were stored at room temperature until DNA extraction. All samples were stored in an environmentally controlled room under conditions with $21 \pm 1{ }^{\circ} \mathrm{C}$ and $44 \pm 5 \%$ relative humidity. Temperature and humidity were recorded using onset Hobo instrument (MA, USA).

\section{DNA extraction methods}

All samples were stored at room temperature for a short-term period of 130 days. DNA extraction was conducted at various time periods (days 1, 7, 30, 45, 90 and 130) to assess the efficacy of DNA preservation methods. The DNA extraction from DNA/RNA Shield was performed using the manufacturer's commercial DNA isolation kit (Zymo Research). According to the instructions, $200 \mu \mathrm{l}$ BioFluid and Cell Buffer and $20 \mu$ proteinase $\mathrm{K}$ were added to the DNA/RNA Shield sample. The mixture was vortexed for $15 \mathrm{~s}$ and then incubated at $55^{\circ} \mathrm{C}$ for $10 \mathrm{~min}$. After incubation, 1 volume of genomic binding buffer was added to the digested sample and the mix was vortexed for $15 \mathrm{~s}$. The mixture was transferred to a Zymo-Spin column in a collection tube and centrifuged at $12,000 \times g$ for 1 min. The collection tube was discarded after centrifugation and $400 \mu$ DNA Pre-Wash buffer was added to the spin column in a new collection tube and centrifuged at $12,000 \times g$ for $1 \mathrm{~min}$. Then the collection tube was emptied and $700 \mu \mathrm{g}$-DNA wash buffer was added to the spin column and the tube was centrifuged at $12,000 \times g$ for $1 \mathrm{~min}$. This step was repeated by adding $200 \mu \mathrm{l}$-DNA wash buffer to the collection tube. After centrifugation, the spin column was transferred to a clean microcentrifuge tube and $50 \mu$ DNA Elution buffer was added directly on the matrix. The microcentrifuge tube was incubated for $5 \mathrm{~min}$ at room temperature, then centrifuged at maximum speed for $1 \mathrm{~min}$ to elute the DNA. The eluted DNA was quantified by the BioDrop spectrophotometer, measuring absorbance at 260/280 nm (BioDrop, Cambridge, UK).

The DNA extraction from DBSs (paper towel, blotting paper and FTA classic cards) was performed by following Tris-EDTA (TE) and $\mathrm{NaOH}$ protocols.

\section{TE protocol}

From each cellulosic material (paper towel, blotting paper and FTA classic card), ten 1.5-mm diameter disks were punched and then the DBSs transferred into 1.5-ml microcentrifuge tubes. $500 \mu \mathrm{d} \mathrm{H}_{2} \mathrm{O}$ was applied to the disks and the tubes were shaken for 5 min at $37^{\circ} \mathrm{C}$ and $50 \times g$. The wash procedure was repeated three more times, discarding the $\mathrm{dH}_{2} \mathrm{O}$ for every interval. After the washing stage, $500 \mu \mathrm{l}$ TE buffer (10 mM Tris, $10 \mathrm{mM}$ EDTA, pH 8.0) and $10 \mu$ proteinase $\mathrm{K}$ were added onto the discs and the samples were then vortexed for $15 \mathrm{~s}$. After vortexing, the samples were incubated at $37^{\circ} \mathrm{C}$ overnight in the shaker $(50 \times g)$. No red blood cell lysis buffer was needed in this study because chicken blood has nucleated erythrocytes. However, for non-nucleated erythrocyte blood samples, it is recommended that a red blood cell lysis buffer ( $0.32 \mathrm{M}$ sucrose, $10 \mathrm{M}$ EDTA, $5 \mathrm{mM} \mathrm{MgCl}$ ) is used at this stage. After incubation, all samples were vortexed for $15 \mathrm{~s}$. Then, to increase extraction efficiency, cell lysates were incubated at $95^{\circ} \mathrm{C}$ for 15 min and then cooled at room temperature for $10 \mathrm{~min}$. A short vortex was performed after incubation. Then the samples were centrifuged at $13,000 \times g$ for $1 \mathrm{~min}$ and the DNA-containing supernatants were stored at $-80^{\circ} \mathrm{C}$ until analysis. The DNA concentrations were determined by the BioDrop spectrophotometer measuring the absorbance at $260 / 280 \mathrm{~nm}$.

\section{$\mathrm{NaOH}$ protocol}

The $\mathrm{NaOH}$ method is another method for isolating DNA from DBSs. We used the $\mathrm{NaOH}$ method to extract DNA from cellulosic materials (paper towel, blotting paper and classic FTA card). Ten 1.5-mm diameter disks were punched from each cellulosic material and transferred into $1.5-\mathrm{ml}$ microcentrifuge tubes, then $200 \mu \mathrm{l} \mathrm{NaOH}(20 \mathrm{mM})$ was added to each sample and agitated for $30 \mathrm{~min}$ at room 


DNA/RNA shield $\quad$ FTA cards Blotting paper $\quad$ Paper towel

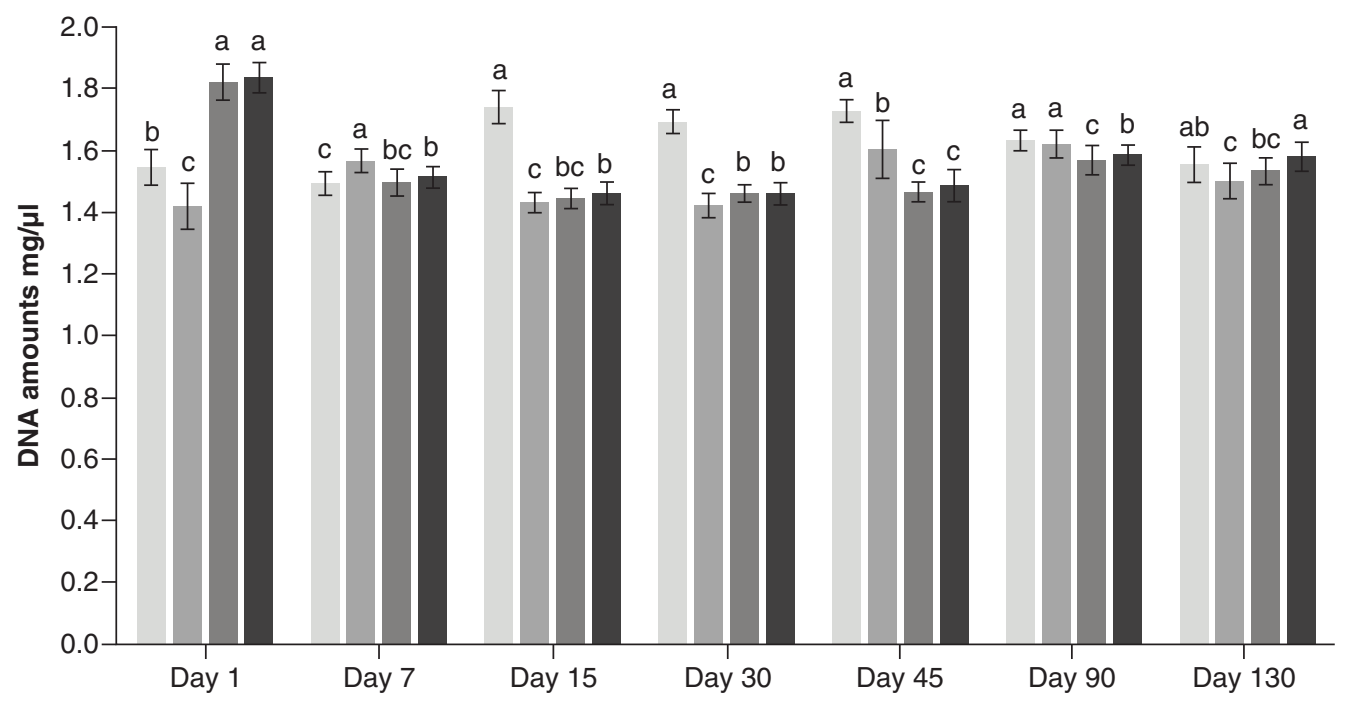

Figure 1. DNA amounts of samples isolated from different preservation methods using the Tris-EDTA protocol. Error bars denote one standard deviation around the mean and ${ }^{a, b, c}$ letters on the bars of the same storage day indicate significant differences $(p<0.05)$. Each value represents the mean of all replicates $(n=30)$.

temperature on a horizontal shaker $(50 \times g)[19]$. The $\mathrm{NaOH}$ was then discarded and discs were washed by $\mathrm{TE}^{-1}$ buffer $(10 \mathrm{mM}$ Tris- $\mathrm{HCl}$, 0.1mM EDTA, pH 8.0) twice for 2 min. Discs were then dried at room temperature for $6 \mathrm{~h}$.

\section{Polymerase chain reaction}

The quality of the extracted DNA was determined by PCR amplification of chicken CHD1 gene fragment. The CHD1 gene fragment was amplified using primers P2 forward (TCTGCATCGCTAAATCCTTT) and P8 reverse (CTCCCAAGGATGAGRAAYTG) (Sentebiolab, Ankara, Turkey). The amplification was performed in a total $20 \mu$ reaction volume containing $2 \mu l$ extracted DNA (DNA samples extracted with TE protocol) or DNA on cellulosic discs (DNA samples extracted with $\mathrm{NaOH}$ method), $0.5 \mu \mathrm{l}$ of each primer, $4 \mu \mathrm{l}$ reaction buffer (Bioline, MA, USA), $0.2 \mu \mathrm{l}$ Taq polymerase (Bioline, MA, USA) and $12.8 \mu \mathrm{dH}_{2} \mathrm{O}$. The amplification was executed in a thermal cycler (Thermo Fisher Scientific, Vantaa, Finland) and cycling conditions were as follows: an initial denaturation of $5 \mathrm{~min}$ at $95^{\circ} \mathrm{C}$, followed by 35 cycles of $95^{\circ} \mathrm{C}$ for $30 \mathrm{~s}, 60^{\circ} \mathrm{C}$ for $1 \mathrm{~min} 30 \mathrm{~s}$ and $72^{\circ} \mathrm{C}$ for $45 \mathrm{~s}$, concluding with $30 \mathrm{~min}$ at $60^{\circ} \mathrm{C}$ and $\infty$ min at $15^{\circ} \mathrm{C}$. Amplimers $(2 \mu \mathrm{l})$ were analyzed by $1 \%$ agarose (Bioreagent) gel electrophoresis using $1 \times$ TBE buffer (Grisp) containing $2 \mu$ ethidium bromide and then gels were visualized by transillumination (Ingenius Syngene, Cambridge, UK).

\section{Band intensity quantification}

The signal intensity of the PCR product bands in the gel was quantified by ImageJ software [20]. To optimize the image analysis, all gel images were converted to 8-bit and the background image was subtracted from the original 8-bit image in order to generate an image with detectable bands and a uniformly subtracted background. After calibration, the densitometric area of each PCR amplicon was calculated using the gel analyzer module of ImageJ. Logarithmic transformation (log10) was applied to densitometric values to normalize the data.

\section{Statistical analysis}

Data were analyzed statistically by IBM SPSS Statistics Base v23 (IBM Corp., NY, USA). The general linear model was used to test the DNA preservation ability of different DNA storage methods. Bonferroni and Duncan's post hoc tests were performed to compare the DNA amounts isolated from different DNA storage methods at different storage durations.

\section{Results \& discussion}

DNA was fixed on cellulose discs in the $\mathrm{NaOH}$ method, and these discs were used as a direct DNA source in the PCR process. Thus samples of DNA extracted using the $\mathrm{NaOH}$ protocol could not be spectrophotometrically analyzed. The amount of DNA isolated from DBSs (paper towel, blotting paper and FTA classic card) by the TE method and the amount of DNA isolated from DNA/RNA Shield are shown in Figure 1, by type of DNA storage method and storage duration. Among the DBS samples, the minimum DNA amount was detected in 


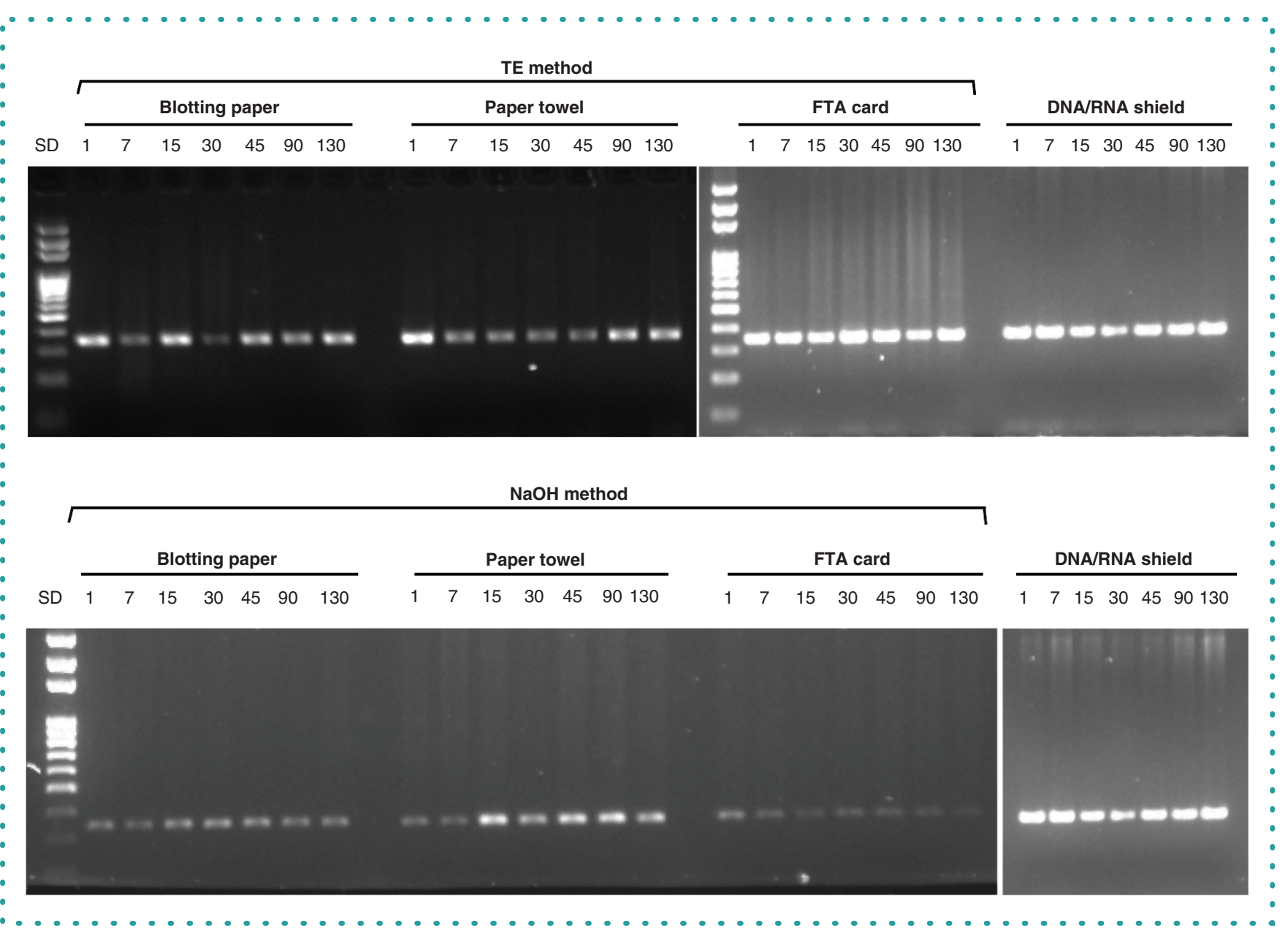

Figure 2. PCR amplification efficiency of DNA samples extracted using Tris-EDTA and NaOH methods from different DNA storage methods on different days.

*Blood samples stored in the DNA/RNA Shield were extracted using the specific DNA kit (Zymo Research).

SD: Storage days from 1 st to 130 th day.

FTA classic card samples at day $1(1.42 \mathrm{mg} / \mu \mathrm{l})$ while the greatest amounts of DNA were detected in paper towel samples $(1.84 \mathrm{mg} / \mu \mathrm{l})$ and blotting paper samples $(1.82 \mathrm{mg} / \mu \mathrm{l})$ at day 1 . The mean amounts of DNA extracted from FTA classic card, paper towel and blotting paper were $1.51 \pm 0.05 \mathrm{mg} / \mu \mathrm{l}, 1.56 \pm 0.04 \mathrm{mg} / \mu \mathrm{l}$ and $1.54 \pm 0.04 \mathrm{mg} / \mu \mathrm{l}$, respectively. The DNA/RNA Shield, performed with the manufacturer's DNA kit, had the highest mean value $(1.63 \mathrm{mg} / \mu \mathrm{l})$ of DNA among the DNA preservation methods during the 130-day period. The difference among storage methods was significant $(p<0.05)$ in terms of the mean amount of DNA in the same storage period (Figure 1).

The CHD1 gene has been amplified by PCR to determine the consistency of all extracted DNA samples. Amplification of the CHD1 gene fragment from DNA samples extracted from DBSs with the TE method is shown in Figure 2. The 450-bp fragment of $C H D 1$ was successfully amplified from the fresh and the stored DNA samples extracted from DBSs (paper towel, blotting paper and FTA classic cards) with the TE method.

Although DNA quality was sufficient for all samples extracted from DBSs using the TE method, the samples extracted from FTA classic cards showed more intense bands than samples extracted from blotting paper and paper towel. As a commercial control, the bands were the most intense for DNA/RNA Shield samples which were isolated using the DNA kit without the TE or NaOH protocol. The PCR amplifications for DNA samples extracted with $\mathrm{NaOH}$ protocols were less dense than those obtained from DNA samples extracted with TE protocols (Figure 2). Compared with blotting paper and FTA cards, PCR activity of DNA samples isolated from paper towels with the $\mathrm{NaOH}$ protocol was the highest.

Digital analysis was performed with ImageJ to quantify the densitometric area of band intensities and to compare the PCR efficiency of DNA samples extracted from different storage methods through different extraction methods (Figures 3 \& 4). Digital quantification of the PCR amplicons supported the qualitative gel image evaluation. According to the densitometric analysis of PCR amplicons from the TE method, FTA cards showed the highest mean optical density (3.92; range: 3.83-3.98), while the mean optical densities for paper 

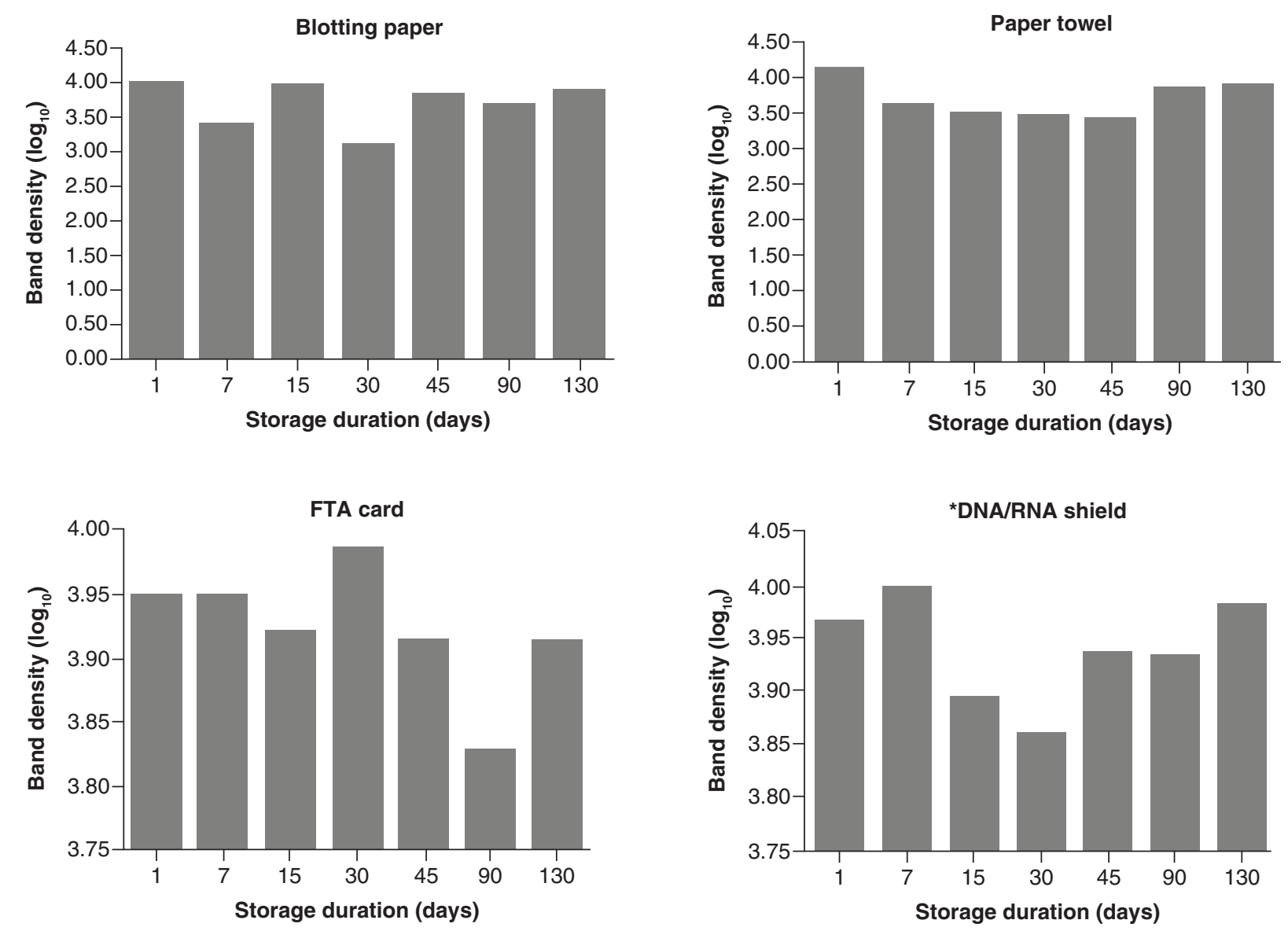

Figure 3. Densitometric analysis of PCR band signals of DNA samples extracted with the Tris-EDTA protocol in terms of DNA storage methods and storage duration.

*Blood samples stored in the DNA/RNA Shield were extracted using a specific DNA kit (Zymo Research) without the Tris-EDTA protocol.

towel and blotting paper were 3.68 and 3.66, respectively (Figure 3). The band densities of the samples extracted from the paper towel with the TE method were in the range 3.40-4.11 and showed the least variation among other DNA preservation methods (Figure 3). The densitometric quantification of PCR bands of DNA samples extracted by the $\mathrm{NaOH}$ method is shown in Figure 4 . The paper towel samples showed the highest band intensities (mean: 3.60; range: 3.28-3.78). In contrast to the TE method, the lowest band densities in the $\mathrm{NaOH}$ method were seen in the FTA group, with an average of 3.08, while the average band density in the samples extracted from the blotting paper was 3.44. When the PCR band densities of DBS samples extracted with TE and $\mathrm{NaOH}$ methods were compared with those of the DNA/RNA Shield samples extracted with DNA kit, the DNA/RNA Shield samples were found to have a denser band, with a mean of 3.94 .

Preservation and transportation of blood samples obtained from animals to the laboratory without the degradation of DNA is a major challenge for researchers during field studies. To find a solution to this problem, some products have been developed for the preservation of DNA from sample uptake to the analysis stage. Cellulose's ability to bind DNA molecules has made it a suitable material for products aimed at preserving DNA. Thus various commercial DNA preservation methods were produced by taking this property of cellulose into account and a large proportion of those products in the most common use are cellulose based. The cellulose-based FTA cards are one of the most effective and widely used DNA preservation and storage products that can preserve DNA in dry conditions at room temperature for long periods of time. With a similar approach using cellulose's DNA binding ability, cellulose-based paper towel and blotting paper were tested as low-cost alternatives to DNA preservation products.

Spectrophotometric DNA quantification results have shown that paper towel has a truly staggering level of DNA binding capacity. According to the results of the BioDrop analysis, the mean amount of DNA extracted from paper towel samples was the highest after 


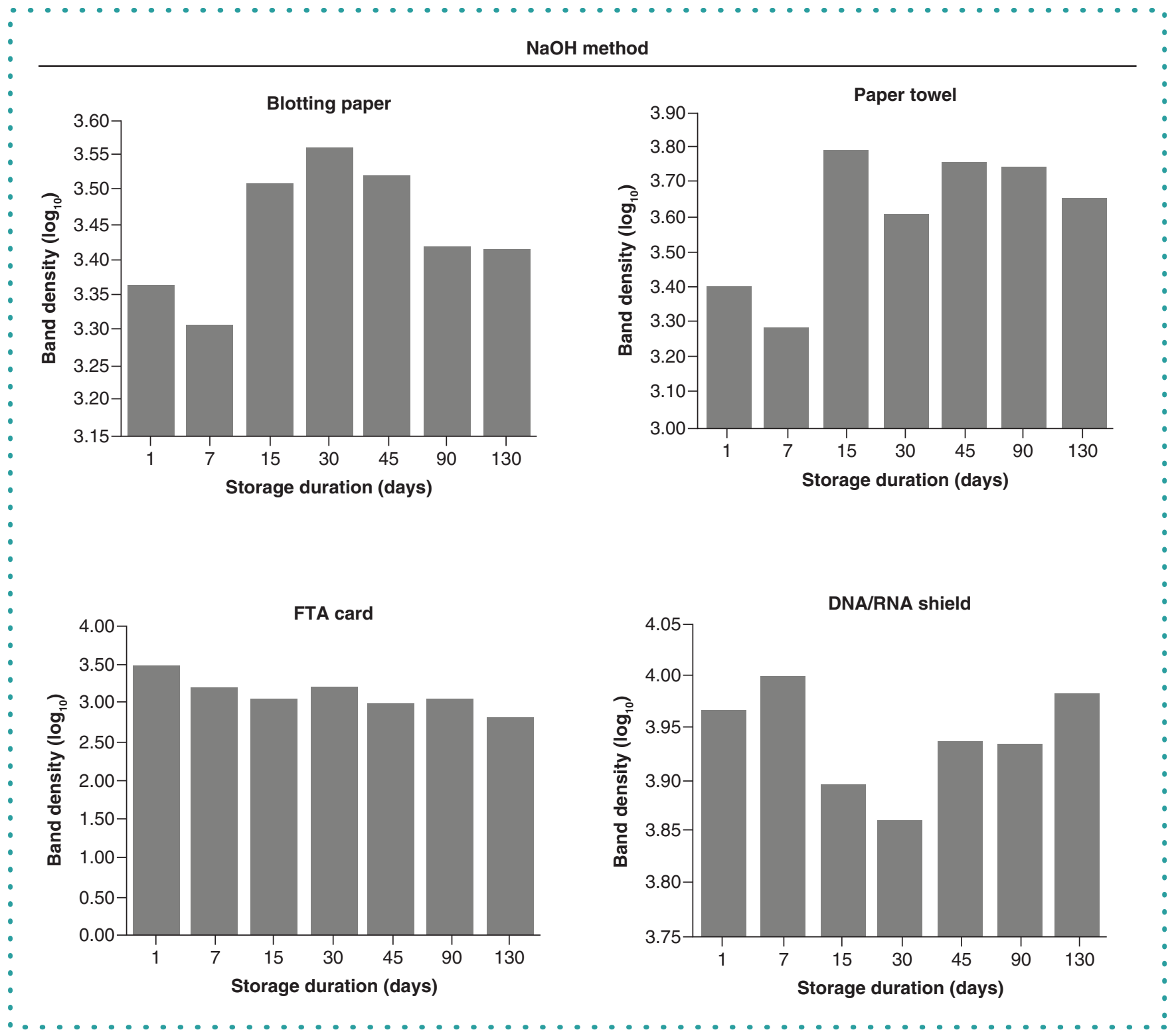

Figure 4. Densitometric analysis of PCR band signals of DNA samples extracted with the $\mathrm{NaOH}$ protocol in terms of DNA storage methods and storage duration.

*Blood samples stored in the DNA/RNA Shield were extracted using a specific DNA kit (Zymo Research) without the NaOH method.

the mean amount of DNA extracted from DNA/RNA Shield. DNA samples on paper towels showed better results for PCR performance with both $\mathrm{TE}$ and $\mathrm{NaOH}$ extraction methods than blotting paper samples, and paper towel samples even showed a more successful PCR performance in the $\mathrm{NaOH}$ method than FTA classic cards. This result may be related to the cellulose densities of the materials chosen as the preservation method. Moreover, the number of cellulose disks used in the DNA extraction could have an inverse effect on the amount of DNA amplified, which could result in greater sequestration of primers, dNTPs or other reagents in the amplification reaction [21]. Therefore paper towel samples, which are less dense in terms of cellulose content, had more successful amplification efficiency in the $\mathrm{NaOH}$ method, due to the fact that the cellulose density is higher in blotting paper and FTA classic cards.

In the current study, the FTA classic cards with successful results from the TE method did not show the same success with the $\mathrm{NaOH}$ extraction method. However, because the purification reagent specific to FTA classic cards was not used and DNA extraction was performed by TE and $\mathrm{NaOH}$ methods, it may not be the right approach to interpret the results for FTA classic cards. Another commercial DNA preservation product in the study, DNA/RNA Shield, showed highly successful results of the spectrophotometric analysis, gel electrophoresis images and digital quantification analysis across storage duration with the use of the product-specific extraction kit. 
Although products such as FTA classic cards and DNA/RNA Shield allow DNA to be stored intact for long periods of time at room temperature, their costs limit the use of these products for low-budget research. Moreover, cooling or freezing samples immediately after sampling is a troublesome and stressful process for researchers in field studies. Although liquid nitrogen or dry ice may appear to be ideal methods for cooling or freezing samples until the laboratory stage, they are not very practical applications for long-term field studies in the preservation of molecules that are negatively affected by external conditions, such as DNA/RNA.

In conclusion, the results of this study demonstrated that cellulose-based blotting paper and especially paper towel had considerable DNA binding and preservation capacity for at least 130 days at room temperature without DNA degradation. The 130-day preservation period provided by the paper towel can be seen as a short period when compared with products such as FTA classic cards and DNA/RNA Shield that can store DNA for many years. However, the 130-day short-term preservation performance of the paper towel provides enough time to researchers for transporting the samples from the field to the laboratory without DNA degradation. According to the findings of this study, the paper towel has proven to be an adequate, low-cost and reliable short-term DNA preservation method that can be used for backing up samples or as an alternative to high-cost DNA preservation products.

\section{Future perspective}

The processing of animal blood samples for genomic DNA extraction is one of the important aspects of molecular studies on animals, and the preservation and transport of blood samples collected from animals to the laboratory without the degradation of DNA is a significant challenge for researchers during field experiments. This simple and cost-effective short-term DNA storage method is expected to save researchers from the cost of cold-chain applications and high-priced DNA preservation products in future field studies. Although the DNA preservation ability of paper towels seems to be successful in the short term, its long-term success in safeguarding DNA also needs to be tested. Therefore we would like to test the long-term preservation success of paper towels, as well as the potential degradation levels for short and long DNA fragments by performing real-time PCR in the future.

\section{Executive summary}

- This study showed that cellulose-based paper towel can preserve genomic DNA under room temperature conditions without degradation.

This cost-effective, practical and reliable technique can be an inexpensive alternative to high-cost DNA preservation products.

\section{Acknowledgments}

The author would like to thank L Bener, PhD student in Akdeniz University Institute of Natural and Applied Sciences, for assisting with the laboratory practices.

\section{Financial \& competing interests disclosure}

The author has no relevant affiliations or financial involvement with any organization or entity with a financial interest in or financial conflict with the subject matter or materials discussed in the manuscript. This includes employment, consultancies, honoraria, stock ownership or options, expert testimony, grants or patents received or pending, or royalties.

No writing assistance fund has been used in the creation of this manuscript

\section{Ethical conduct of research}

The blood samples used in this study were provided from the experiment material of project BAP-2019-4824, all experimental protocols were approved by Akdeniz University Council for Ethical Licensing of Animal Experiments, ethical permit no. 828/2019.01.01.

\section{Open access}

This work is licensed under the Attribution-NonCommercial-NoDerivatives 4.0 Unported License. To view a copy of this license, visit http://creativecommons.org/licenses/by-nc-nd/4.0/

\section{References}

Papers of special note have been highlighted as: $\bullet$ of interest; $\bullet \bullet$ of considerable interest

1. Michaud CL, Foran DR. Simplified field preservation of tissues for subsequent DNA analyses. J. Forensic Sci. 56(4), 846-852 (2011).

2. Straube D, Juen A. Storage and shipping of tissue samples for DNA analyses: a case study on earthworms. Eur. J. Soil Biol. 57, 13-18 (2013).

- Compares different DNA preservation and extraction methods.

3. Chace DH, Spitzer AR, De Jesus VR. Applications of dried blood spots in newborn and metabolic screening. Wil. Ser. Pharm. Sci. Bi. 53-75 (2014). https://onlinelibrary.wiley.com/doi/10.1 002/9781118890837.ch6

4. Thompson MM, Hrabak EM. Capture and storage of plant genomic DNA on a readily available cellulose matrix. BioTechniques 65(5), 285-287 (2018).

-. Highlights the DNA preservation ability of cellulose.

5. Gruner N, Stambouli O, Ross RS. Dried blood spots - preparing and processing for use in immunoassays and in molecular techniques. J. Vis. Exp. (97), 52619 (2015).

6. Schmidt V. Ivar Christian Bang (1869-1918), founder of modern clinical microchemistry. Clin. Chem. 32(1), $213-215$ (1986). 
7. Scriver CR. A simple phenylalanine method for detecting phenylketonuria in large populations of newborn infants, by Robert Guthrie and Ada Susi, Pediatrics, 1963;32: $318-343$ : Commentary. Pediatrics 102(1), 236-237 (1998).

8. Smit PW, Sollis KA, Fiscus S et al. Systematic review of the use of dried blood spots for monitoring HIV viral load and for early infant diagnosis. PLoS ONE 9(3), e86461 (2014).

9. Lehner AF, Rumbeiha W, Shlosberg A et al. Diagnostic analysis of veterinary dried blood spots for toxic heavy metals exposure. J. Anal. Toxicol. 37(7), 406-422 (2013).

10. Ozdemir D, Cassandro M. Assessment of the population structure and genetic diversity of Denizli chicken subpopulations using SSR markers. Ital. J. Anim. Sci. 17(2), 312-320 (2018).

11. Reichert S, Froy H, Boner W et al. Telomere length measurement by qPCR in birds is affected by storage method of blood samples. Oecologia 184(2), 341-350 (2017).

12. Wickremsinhe ER, Perkins EJ. Using dried blood spot sampling to improve data quality and reduce animal use in mouse pharmacokinetic studies. J. Am. Assoc. Lab. Anim. 54(2), 139-144 (2015).

- Highlights the usage and the efficency of dried blood spots in animal studies.

13. Dittakavi S, Jat RK, Mullangi R. Quantitative analysis of enasidenib in dried blood spots of mouse blood using an increased-sensitivity LC-MS/MS method: application to a pharmacokinetic study. Biomed. Chromatogr. 33(6), e4491 (2019).

14. Lauwers M, Croubels S, De Baere S et al. Assessment of dried blood spots for multi-mycotoxin biomarker analysis in pigs and broiler chickens. Toxins 11 (9), 541 (2019).

15. Raju KSR, Taneja I, Rashid M, Sonkar AK, Wahajuddin M, Singh SP. DBS-platform for biomonitoring and toxicokinetics of toxicants: proof of concept using LC-MS/MS analysis of fipronil and its metabolites in blood. Sci. Rep. 6, 22447 (2016).

16. Tang RH, Yang H, Choi JR et al. Advances in paper-based sample pretreatment for point-of-care testing. Crit. Rev. Biotechnol. 37(4), 411-428 (2017).

17. Lee CE, Ponnampalavanar SS, Omar SFS, Mahadeva S, Ong LY, Kamarulzaman A. Evaluation of the dried blood spot (DBS) collection method as a tool for detection of HIV Ag/Ab, HBsAg, anti-HBs and anti-HCV in a Malaysian tertiary referral hospital. Ann. Acad. Med. Singap. 40(10), 448-453 (2011).

18. Heim BC, Ivy JA, Latch EK. A suite of microsatellite markers optimized for amplification of DNA from addax (Addax nasomaculatus) blood preserved on FTA cards. Zoo. Biol. 31(1), 98-106 (2012).

19. Zhou H, Hickford JGH, Fang Q. A two-step procedure for extracting genomic DNA from dried blood spots on filter paper for polymerase chain reaction amplification. Anal. Biochem. 354(1), 159-161 (2006)

-. An alternative DNA isolation method from dried blood spots.

20. Schneider CA, Rasband WS, Eliceiri KW. NIH Image to ImageJ: 25 years of image analysis. Nat. Methods 9(7), 671-675 (2012).

21. Zou YP, Mason MG, Wang YL et al. Nucleic acid purification from plants, animals and microbes in under 30seconds. PLoS Biol. 15(11), e2003916 (2017). 